\title{
Perbedaan Lama Fotoperiode Terhadap Total Lipid Kultur Mikroalga Chlorella vulgaris
}

\author{
Hendrik Surya Bahar, Ali Djunaedi, Widianingsih* \\ Departemen IImu Kelautan, Fakultas Perikanan dan IImu Kelautan, Universitas Diponegoro \\ J. Prof.H.Soedarto S.H, Tembalang,Semarang, Jawa Tengah 50275 Indonesia \\ *Corresponding author, e-mail : widia2506@gmail.com
}

\begin{abstract}
ABSTRAK: Chlorella vulgaris merupakan salah satu mikroalga yang mengandung lipid, oleh karena itu mikroalga $C$. vulgaris dapat dimanfaatkan sebagai sumber pangan fungsional dalam meningkatkan kesehatan. Pertumbuhan mikroalga dipengaruhi oleh berbagai macam faktor lingkungan salah satunya adalah cahaya. Penelitian ini bertujuan untuk mengetahui fotoperiode terbaik guna meningkatkan pertumbuhan dan kandungan total lipid pada $C$. vulgaris. Metode yang digunakan adalah eksperimen laboratoris. Mikroalga $C$. vulgaris dikultivasi dengan 4 perlakuan siklus fotoperiode (terang:gelap) yang berbeda yaitu A (4:20), B (8:16), C (12:12) dan D ( 24 : $0)$. Penelitian ini menggunakan pupuk walne. Suhu air pada penelitian ini berkisar antara $18-21^{\circ} \mathrm{C}$. Salinitas berkisar antara 29-32 ppt, kisaran pH pada penelitian ini antara 7,3-8,0. Pertumbuhan $C$. vulgaris diamati selama 9 hari kemudian dipanen untuk perhitungan biomassanya. Biomassa basah hasil kultivasi dikeringkan dan dilakukan uji kadar air. Total lipid ditentukan secara gravimetrik. Biomassa disoxhletasi menggunakan n-heksan. Fraksi lipid dan n-heksan dipisahkan dengan distilator, berat ekstraknya terhitung sebagai kandungan total lipid. Hasil penelitian menunjukkan bahwa perlakuan fotoperiode berpengaruh secara nyata $(p<0,05)$ terhadap kepadatan sel mikroalga dan kandungan total lipidnya $C$. vulgaris. Perlakuan $D$ memiliki hasil kepadatan tertinggi sebesar $1.131 \times 10^{4} \mathrm{sel} / \mathrm{mL}$. Perlakuan $\mathrm{C}$ memiliki hasil kandungan total lipid tertinggi dengan total $17 \%$. Perlakuan A memperoleh hasil terendah dengan kepadatan sebesar $638 \times 10^{4}(\mathrm{sel} / \mathrm{mL})$ dan kandungan total lipid 8,7\%.
\end{abstract}

Kata kunci: Chlorella vulgaris; fotoperiode; pertumbuhan; kandungan total lipid

\section{Growth and Total Lipid Content in Microalgae Chlorella vulgaris (Beijerinck, 1890) with Different Light Photoperiods}

ABSTRACT: Chlorella vulgaris is one of the microalgae containing lipids, therefore the microalgae C. vulgaris can be used as a source of functional food to improve health. Microalgae growth is influenced by various environmental factors, one of which is light. This study aims to determine the best photoperiod to increase growth and total lipid content of $C$. vulgaris. The method used is a laboratory experiment. Microalgae $C$. vulgaris was cultivated with 4 different photoperiod (light:dark) cycle treatments, namely $A(4: 20), B(8: 16), C(12: 12)$ and $D(24: 0)$. This research uses walne fertilizer. During the study, water quality measurements were carried out. The water temperature in this study ranged from $18-21^{\circ} \mathrm{C}$. Salinity ranged from $29-32 \mathrm{ppt}$, the $\mathrm{pH}$ range in this study was between 7.3-8.0. The growth of $C$. vulgaris was observed for 9 days and then harvested for biomass calculation. The wet biomass from the cultivation was dried and the moisture content was tested. Total lipid was determined gravimetrically. Biomass was disoxhletated using $n$-hexane. The lipid fraction and n-hexane were separated by distillation, the weight of the extract was calculated as the total lipid content. The results showed that the photoperiod treatment had a significant $(p<0.05)$ effect on the cell density of $C$. vulgaris microalgae and also significantly $(p<0.05)$ on the total lipid content. Treatment $D$ had the highest density of $1,131 \times 104 \mathrm{cells} / \mathrm{mL}$. Treatment $C$ had the highest total lipid content with a total of $17 \%$. Treatment $A$ obtained the lowest yield with a density of $638 \times 104$ (cells $/ \mathrm{mL})$ and a total lipid content of $8.7 \%$.

Keywords: Chlorella vulgaris; photoperiod; growth; total lipid content 


\section{PENDAHULUAN}

Pertumbuhan penduduk menyebabkan memburuknya kerawanan pangan global. Lebih lanjut, pandemi COVID-19 saat ini telah memperburuk risiko kelaparan dan krisis kelaparan. Sekitar 265 juta orang akan menderita kondisi kelaparan kritis pada akhir tahun 2020 (Laborde et al., 2020). Mikroalga memiliki prospek yang bagus sebagai sumber pangan alternatif dengan kualitas dan nilai gizi yang tinggi (Niccolai et al.,2019). Lipid fungsional/ PUFA menurut para ahli dapat mengurangi beban yang dipicu oleh penyakit tidak menular seperti malnutrisi dan diet yang tidak seimbang (Xu et al.,2016). Lipid fungsional seperti PUFA dianggap sebagai elemen penting dari diet manusia, tetapi manusia tidak dapat mensintesisnya sendiri dan perlu disediakan dari luar melalui makanan fungsional (Morales et al.,2019).

Mikroalga merupakan salah satu produsen metabolit sekunder yang layak untuk menjadi pangan fungsional (Galasso et al., 2019). Mikroalga mengandung asam lemak omega-3 dan 6 yang merupakan asam lemak tak jenuh ganda rantai panjang esensial (LC-PUFAs) yang harus dimasukkan dalam makanan sehari-hari karena tidak dapat disintesis oleh manusia dan banyak hewan (Khan et al.,2018). Biomassa mikroalga telah banyak digunakan di berbagai industri: farmasi, makanan fungsional, pakan ternak, pemurnian air, dan produksi biofuel (Barkia et al.,2019) . Dalam kondisi yang sesuai, mikroalga mengubah energi matahari menjadi energi kimia senyawa yang terakumulasi dalam sel mereka, termasuk lipid, yang dapat digunakan dalam produksi pangan alternatif (Chen et al, 2013). Hasil biomassa dan komposisi biokimia mikroalga tergantung pada faktor lingkungan dan fisiologis seperti suhu kultur, $\mathrm{pH}$, intensitas cahaya, fotoperiode cahaya, ketersediaan nutrisi, dan karbon dioksida (Chen et al., 2013).

Chlorella vulgaris merupakan spesies yang telah dipelajari secara ekstensif untuk berbagai tujuan, seperti produksi biomassa sebagai sumber bahan kimia atau pangan fungsional yang berharga, serta pengolahan air limbah dan pakan budidaya (Nisak et al.,2013). Kuantitas dan kualitas cahaya menentukan jumlah energi yang tersedia bagi organisme fotosintetik untuk melakukan aktivitas metabolisme mereka (Matos et al.,2014).

Fotoperiode terang 16 jam terang dan 8 jam gelap memberikan pengaruh terbaik terhadap pertumbuhan Chlorella sp (Napitulu et al., 2019). Menurut hasil penelitian Ratomski dan Paw (2021), menyatakan bahwa pada pencahayaan selama 18 jam perhari dapat memberikan hasil yang optimal untuk produksi biomassa C.vulgaris dalam sistem fotobioreaktor dengan lampu natrium tekanan tinggi dan dioda pemancar cahaya.

Penelitian ini bertujuan untuk mengetahui pengaruh perlakuan fotoperiode yang berbeda terhadap pertumbuhan sel dan kandungan total lipid pada mikroalga $C$. vulgaris, selain itu untuk Mengetahui siklus fotoperiode terbaik yang dapat memberikan kandungan total lipid paling tinggi pada mikroalga $C$. vulgaris.

\section{MATERI DAN METODE}

Mikroalga C.vulgaris sebagai materi dalam penelitian ini diperoleh dari stok murni Balai Besar Perikanan Budidaya Air Payau (BBPBAP) Jepara. Penelitian ini telah dilakukan sejak bulan Febuari-hingga Maret 2021. Kultivasi dilakukan dengan menggunakan wadah toples kaca 3000 $\mathrm{mL}$ dengan kepadatan awal $375 \times 10^{4} \mathrm{sel} / \mathrm{ml}$. Jumlah biakkan murni $1 / 3$ dari total volume. Sedangkan, media air laut $2 / 3$ dari total volume dengan total volumenya sebanyak $2700 \mathrm{~mL}$ (Nisak et al., 2013). Kualitas air yang diamati yaitu salinitas, suhu dan pH. Salinitas yang diterapkan dalam penelitian ini adalah 30-32 ppt. Selanjutnya suhu diatur agar mikroalga tumbuh optimal, suhu ruangan kultur berkisar $19^{\circ} \mathrm{C}-23^{\circ} \mathrm{C}$. Ukuran $\mathrm{pH}$ yang diterapkan dalam penelitian kali ini dengan nilai berkisar ph 7-8 (Ermavitalini et al., 2019). Aerator diatur agar aliran udara mengalir secara merata. Pupuk yang digunakan dalam penelitian adalah pupuk walne dengan takaran $1 \mathrm{ml} / \mathrm{L}$.

Fotoperiode sebagai perlakukan dilakukan dengan 3 kali ulangan dan untuk pemanenan biomassa dan analisa kadar total lipid dilakukan pada fase stasioner (Ermavitalini et al., 2019). Perlakuan fotoperiode terdiri dari perlakuan A ( 4 jam terang -20 jam gelap), perlakuan B ( 8 jam terang - 16 jam gelap), perlakuan C ( 12 jam terang -12 jam gelap) dan perlakuan D ( 24 jam terang - 0 jam gelap) (Widianingsih et al.,2012). Kepadatan sel $C$. vulgaris dihitung dengan rumus perhitungan (Imron et al.,2016). 
Pelarut non-polar digunakan yaitu n-Heksan dengan metode AOAC (Levasseur et al.,2018) biomassa kering mikroalga $C$. vulgaris ditimbang sebanyak $\pm 1 \mathrm{~g}$, kemudian sampel yang sudah ditimbang dibungkus dengan kertas saring whatman. Pengeringan dilakukan pada labu lemak dalam oven, kemudian ditimbang hingga beratnya konstan. Pelarut n-heksan dimasukkan ke dalam labu lemak dan sampel dimasukkan ke dalam thimble. sampel diusahakan terendam oleh pelarut $n$-heksan, kemudian dilakukan ekstraksi selama 6-8 jam pada suhu $60^{\circ} \mathrm{C}$. Evaporasi campuran lipid dan pelarut dilakukan dengan distilator pada suhu $60^{\circ} \mathrm{C}$, kemudian labu lemak yang berisi ekstrak lipid diletakkan dalam desikator dan ditimbang beratnya (Dewi dan Nuravivah, 2018). Penentuan total lipid pada sampel dilakukan berdasarkan rumus berikut:

$$
\text { Total Lipid }=\frac{(\mathrm{A}-\mathrm{B})}{\mathrm{C}} \times 100 \%
$$

Keterangan : A = Berat labu lemak + ekstrak lemak (g); $B$ = Berat labu lemak kosong $(\mathrm{g})$; $\mathrm{C}=$ berat kering sampel $(\mathrm{g})$

Program SPSS 25 digunakan untuk analisa data. Analisis statistik ini bertujuan untuk mengetahui pengaruh fotoperiode terhadap pertumbuhan dan kandungan lemak total $C$. vulgaris. Analisis statistik menggunakan One Way ANOVA. Sebelumnya dilakukan uji normalitas dan uji homogenitas. Jika hasil ANOVA terlihat berbeda nyata, maka dilakukan uji Tukey HSD. Pengujian ini dirancang untuk mengetahui perbedaan pada setiap level fotoperiode masing-masing perlakuan. mengetahui perbedaan antara perlakuan satu dengan perlakuan yang lain (Kusriningrum, 2012).

\section{HASIL DAN PEMBAHASAN}

Berdasarkan hasil pengamatan pertumbuhan selama 9 hari kultivasi. Perlakuan $D$ memiliki hasil kepadatan sel tertinggi yaitu $1.131 \times 10^{4} \mathrm{sel} / \mathrm{ml}$ pada hari ke -8 kultivasi. Perlakuan $A$ memiliki hasil kepadatan sel terendah yaitu sebanyak $638 \times 10^{4} \mathrm{sel} / \mathrm{ml}$ pada hari ke-8 kultivasi. Hasil tersebut merupakan hasil yang diperoleh pada perhitungan sel pada hari ke-9 kultivasi.

Perlakuan D memiliki kepadatan tertinggi, hal ini diduga pada perlakuan tersebut ketersediaan cahaya sebagai sumber energi proses fotosintesis selalu ada dan pigmen fotosintesis dapat menyerap cahaya foton lebih banyak. Penyerapan energi foton yang tersebut dapat meningkatkan laju fotosintesis dan proses fotosintesis dapat memproduksi senyawa organik lebih banyak guna pertumbuhan bagi mikroalga $C$. vulgaris. Hal tersebut diperkuat dari Yusof et al, (2021). menyatakan bahwa perlakuan fotoperiode siklus (24 terang : 0 gelap) memberikan hasil pertumbuhan sel mikroalga $C$. vulgaris tertinggi dibandngkan dengan perlakuan lainnya. Perlakuan A memiliki hasil kepadatan terendah, hal tersebut diduga fotoperiode mempengaruhi pertumbuhan dan biomassa mikroalga karena sejajar dengan laju fotosintesis dan metabolisme mikroalga (Matos et al., 2014).

Hasil rata-rata analisis kandungan total lipid yang terkandung dalam mikroalga C. vulgaris yang diekstraksi menggunakan soxhlet memiliki nilai yang bervariasi dan disajikan pada (lampiran 5). Hasil analisis menunjukkan pada perlakuan $\mathrm{C}$ memiliki kandungan total lipid tertinggi dengan nilai $17,0 \%$, sedangkan untuk Perlakuan A, B dan D masing-masing memiliki kandungan total lipid terendah dengan nilai $8,7 \%, 11,8 \%$ dan $13,5 \%$. Data kandungan total lipid $C$. vulgaris yang dikultivasi dengan fotoperiode berbeda kemudian diuji uji one way ANOVA (Analysis of Variance). Hasil uji one way ANOVA (Analysis of Variance) menunjukkan hasil dengan nilai signifikansi ( $\mathrm{p}<0,05)$, berarti terdapat perbedaan yang nyata antara taraf perlakuan fotoperiode terhadap kandungan total lipid sel mikroalga $C$. vulgaris.

Fotoperiode memberikan pengaruh lingkungan terhadap sel mikroalga $C$. vulgaris dan memberikan pengaruh dalam biosintesis lipid. Hal ini sesuai Hu et al (2008), menyatakan bahwa cekaman fotperiode merupakan salah satu tindakan rekayasa untuk meningkatkan biosintesis lipid pada mikroalga. Menurut Saad et al. (2019), menyatakan sel mikroalga akan mengalokasikan pertumbuhan biomassa menjadi penyimpanan lipid sebagai adaptasi pertahanan terhadap kondisi lingkungan yang labil.

Pernyatan tersebut mendukung bahwa tekanan fotoperiode mempengaruhi reaksi terang 
dan gelap yang terjadi pada sel mikroalga $C$. vulgaris, sehingga menyebabkan adanya variasi nilai kandungan total lipid dan laju fotosintesis. Perlakuan fotoperiode dengan fase terang yang singkat waktunya akan menurunkan laju pertumbuhan dan mempengaruhi penyerapan tidak optimal energi foton oleh pigmen fotosintesis dan mempengaruhi laju fotosintesis (Novianti dan Sri, 2015). Menurut Atikij et al. (2019), proses biosintesis lipid terjadi saat kloroplas melakukan fiksasi karbon dioksida. Menurut Masojídek et al (2013), menyatakan fiksasi karbondioksida terjadi pada fase gelap dalam proses fotosintesis sel mikroalga. Hasil penelitian menunjukkan perlakuan $\mathrm{C}$ memiliki hasil kandungan total lipid tertinggi.

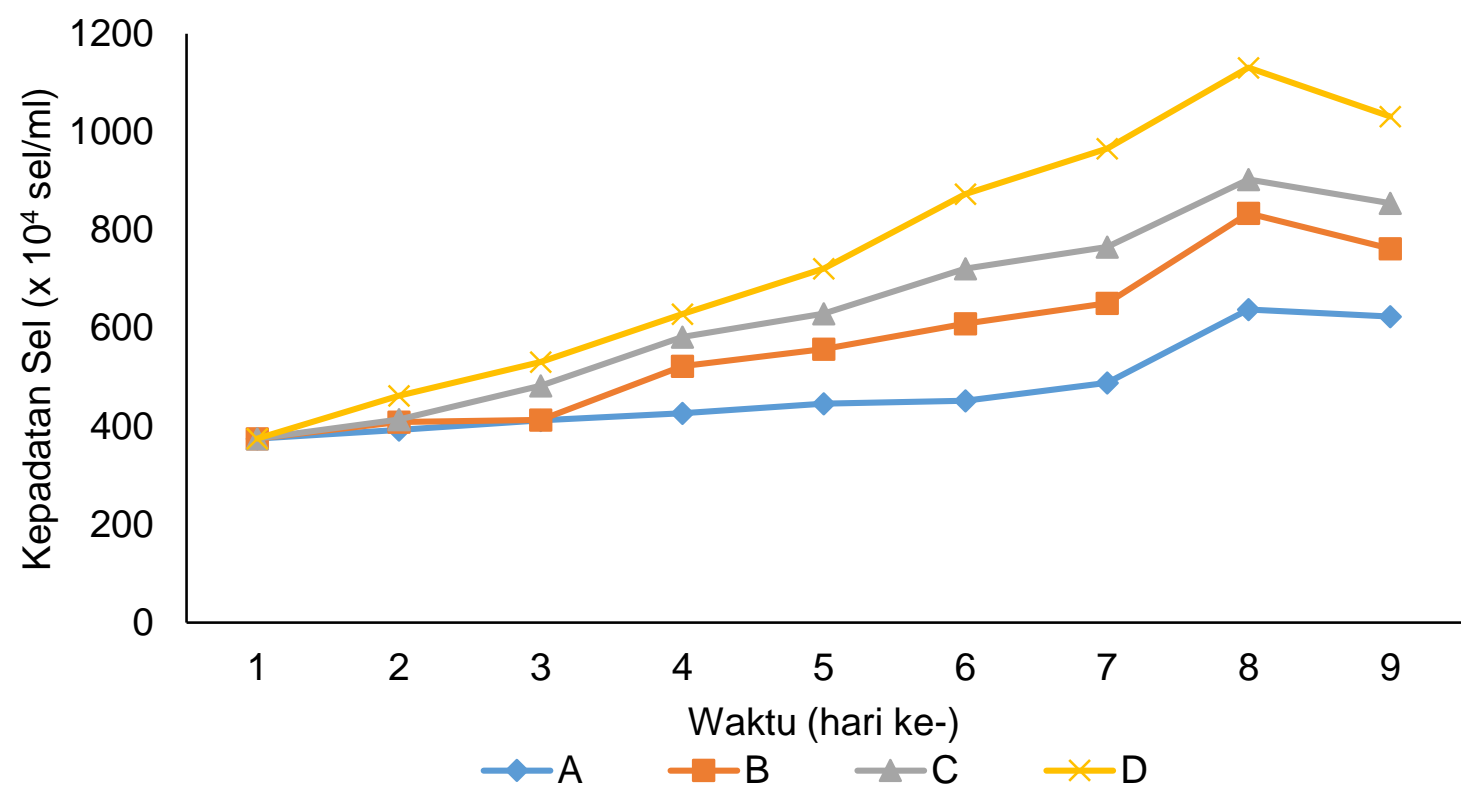

Gambar 1. Pertumbuhan $C$.vulgaris pada kultivasi selama 9 hari dengan fotoperiode berbeda. $(A=$ 4 jam terang 20 jam gelap), ( $B=8$ jam terang 16 jam gelap), $(C=12$ jam terang 12 jam gelap), ( $D=24$ jam terang 0 jam gelap).

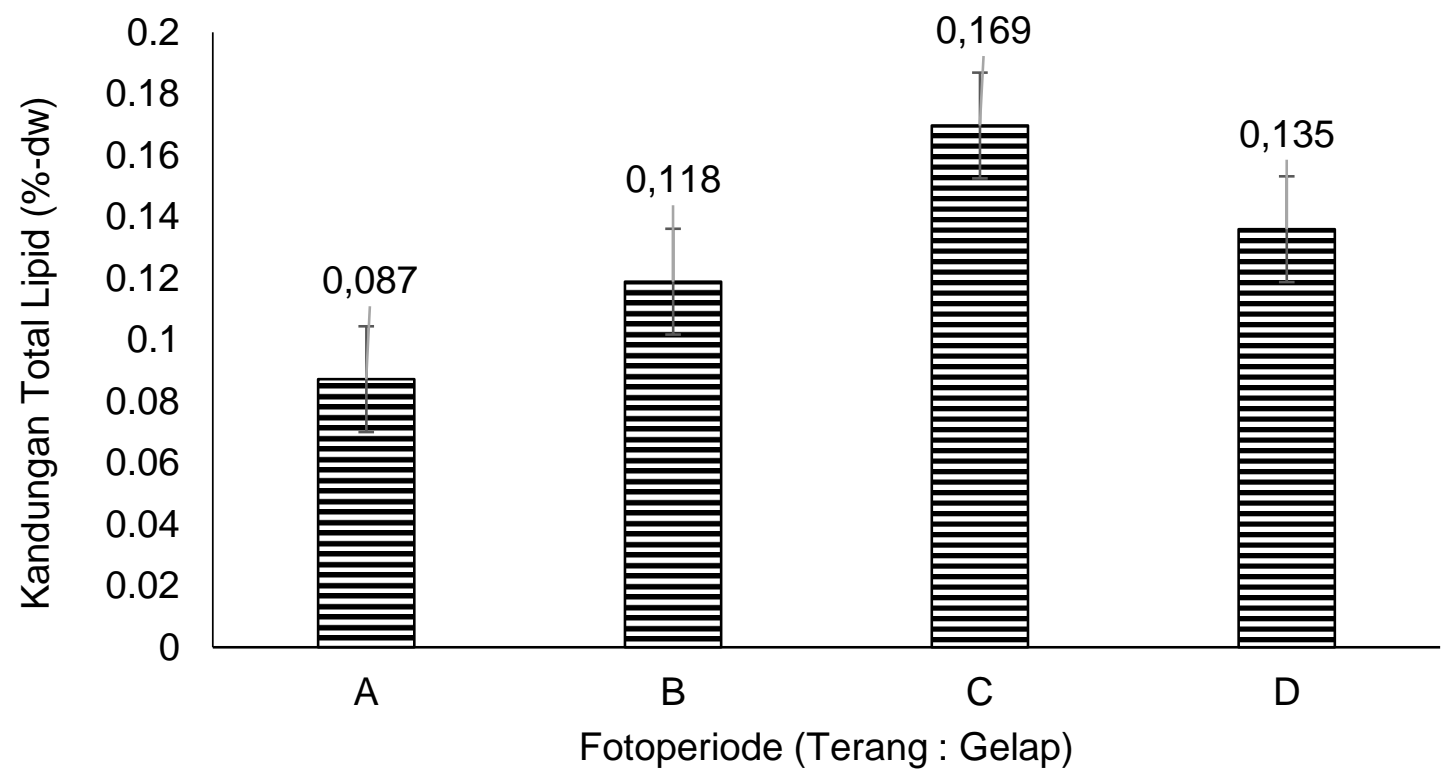

Gambar 2. Nilai Rata-Rata kandungan total lipid Mikroalga C.vulgaris pada kultivasi dengan fotoperiode yang berbeda. ( $A=4$ jam terang 20 jam gelap), $(B=8$ jam terang 16 jam gelap), ( $C=12$ jam terang 12 jam gelap), $(D=24$ jam terang 0 jam gelap). 
Menurut Widianingsih et al. (2012), menyatakan bahwa fotoperiode akan memberikan pengaruh terhadap peningkatan kandungan total lipid total mikroalga pada fase stasioner dan mampu mengurangi pembentukan atau sintesi n-3 polyunsaturated fatty acids (PUFA). Menurut Krzemin'ska et al. (2014), menyatakan bahwa dalam tekanan lingkungan yang tidak menguntungkan, mikroalga dapat mengakumulasi lipid netral dalam bentuk triasilgliserida (TAG) yang dapat digunakan oleh mikroalga untuk bertahan dalam tekanan lingkungan yang periode cahayanya dikurangi. Hal itu diperkuat dari hasil dari penelitian Gammanpila et al. (2015), menunjukkan siklus fotoperiode (12:12) menghasilkan lipid tertinggi dibandingkan dengan siklus fotoperiode yang lain.

\section{KESIMPULAN}

Fotoperiode memberikan pengaruh yang berbeda nyata terhadap kandungan total lipid dan pertumbuhan, tetapi tidak berpengaruh nyata terhadap produksi biomassa kering mikroalga Chlorella vulgaris. Fotoperiode (12:12) memberikan pengaruh kandungan total lipid dengan hasil paling tinggi pada mikroalga Chlorella vulgaris.

\section{DAFTAR PUSTAKA}

Atikij, T., Syaputri, Y., Iwahashi, H., Praneenararat, T., Sirisattha, S., Kageyama, H., \& Sirisattha, R.W. 2019. Enhanced Lipid Production and Molecular Dynamics under Salinity Stress in Green Microalga Chlamydomonas reinhardtii (137C). Marine Drugs, 17(4):1-15. DOI: 10.3390/md17080484

Barkia I, Saari N., \& Manning, S.R. 2019. Microalgae for high-value products towards human health and nutrition. Marine Drugs, 17(5):304. DOI: 10.3390/md17050304.

Chen, C.Y., Zhao ,X.Q., Yen, H.W., Ho, S.H., Cheng, C.L., Lee, D.J., Bai, F.W., \& Chang,J.S. 2013. Microalgae-based carbohydrates for biofuel production. Biochemical Engineering Journal, 78:1-10. DOI: 10.1016/j.bej.2013.03.006

Dewi, E.R.S. \& Nuravivah, R. 2018. Potential of Microalgae Chlorella vulgaris As Bioremediation Agents of Heavy Metal Pb (Lead) On Culture Media. E3S Web of Conferences, 31(05010) : 14. DOI:10.1051/e3sconf/20183105010.

Ermavitalini, D., Dwirejeki, S., Nurhartika, S. \& Saputro, T.B. 2019. Pengaruh Kombinasi Cekaman Nitrogen dan Fotoperiode Terhadap Biomassa, Kandungan Kualitatif Triasilgliserol dan Profil Asam Lemak Mikroalga Nannochloropsis sp. Akta Kimia Indonesia, 4(1):32-49. DOI: 10.12962/j25493736.v4i1.5089

Gammanpila, A.M., Rupasinghe, C.P., \& Subasinghe, S. 2015. Light Intensity and Photoperiod Effect on Growth and Lipid Accumulation of Microalgae Chlorella vulgaris and Nannochloropsis $s p$ for Biodiesel Production. Proceedings of 12 th ISERD International Conference ISBN: 978-93-85832-00-0.

Galasso, C., Gentile, A., Orefice, I., lanora, A., Bruno, A., Noonan, D.M., Sansone, C., Albini, A., \& Brunet, C. 2019. Microalgal derivatives as potential nutraceutical and food supplements for human health: a focus on cancer prevention and interception. Nutrients, 11(6):1226. DOI: 10.3390/nu11061226.

Levasseur, W., Taidi, B., Lacombe, R., Perre, P., \& Pozzobon, V. 2018.Impact of seconds to minutes photoperiods on Chlorella vulgaris growth rate and chlorophyll $\mathrm{a}$ and $\mathrm{b}$ content. Algal Research, 36:10-6.

Hu, Q., Sommerfeld, M., Jarvis, E., Ghirardi, M., Posewitz, M., \& Seibert, M., 2008. Microalgal triacylglycerols as feedstocks for biofuel production: perspectives and advances. The Plant Journal, 54:21-39.

Imron, M.A., Sudarno \& Masithah, E.D. 2016. Pengaruh Salinitas Terhadap Kandungan Lutein pada Mikroalga Botryococcus braunii. Journal of Marine and Coastal Science, 5(1):36 - 48.

Masojídek, J., Torzillo, G., \& Koblížek, M. 2013. Photosynthesis in Microalgae. Handbook of Microalgal Culture, 21-36p. DOI: 10.1002/9781118567166.ch2 
Krzemin'ska, I., Skowron'ska, B. P., Trzcin'ska ,M. \& Tys, J. 2014. Influence of photoperiods on the growth rate and biomass productivity of green microalgae. Bioprocess and Biosystems Engineering, 37: 735-741. DOI: 10.1007/s00449-013-1044-x.

Kusriningrum. 2012. Perancangan Percobaan. Airlangga University Press. Surabaya. Hal 43-69

Laborde, D., Martin, W., Swinnen, J. \& Vos, R., 2020. COVID-19 risks to global food security. Science, 369:500-502. DOI: 10.1126/science.abc4765.

Matos, Â.P., Cavanholi, M.G., Moecke, E.H.S. \& Sant'Anna, E.S. 2014. Effects of different photoperiod and trophic conditions on biomass, protein and lipid production by the marine alga Nannochloropsis gaditana at optimal concentration of desalination concentrate. Bioresource Technology, 224:490-7. DOI: 10.1016/j.biortech.2016.11.004.

Niccolai, A., Zittelli, G.C., Rodolfi, L., Biondi, N., Tredici, M.R., 2019. Microalgae of interest as food source: biochemical composition and digestibility. Algal Research, 42: 101617. DOI: 10.1016/j.algal.2019.101617.

Nisak, K., Rahardjo, B.S. \& Masithah, E.D. 2013. Studi Perbandingan Kemampuan Nannochloropsis sp. dan Chlorella sp. Sebagai Agen Bioremediasi Terhadap Logam Berat Timbal (Pb). Jurnal IImiah Perikanan dan Kelautan., 5(2):175-180. DOI: 10.20473/jipk.v5i2. 11405.

Novianti \& Sri, S. 2015. Effect of Photoperiod During Nitzschia sp. Culture. Against Total Fat Content and Ratio of N P. Thesis. Lampung. Aquaculture Study Program, Faculty of Agriculture. University of Lampung.

Ratomski, P. \& Paw, M.H. 2021. Production of Chlorella vulgaris biomass in tubular Photobioreactors during Different Culture Conditions. Applied Sciences, 11:1-13. DOI: 10.3390/app11073106

Saad, M.G., Dosoky, N.S., Zoromba, M.S. \& Shafik, H.M. 2019. Algal Biofuels : Current Status and Key Cahllenges. Energies., 12(10):1920. DOI:10.3390/en12101920.

Morales, M., Hélias, A. \& Bernard, O. 2019. Optimal integration of microalgae production with photovoltaic panels: environmental impacts and energy balance. Biotechnology for Biofuels and Bioproducts, 12(1):239. DOI: 10.1186/s13068-019-1579-4

Khan, M.I, Shin, J.H., \& Kim, J.D. 2018. The promising future of microalgae: current status, challenges, and optimization of a sustainable and renewable industry for biofuels, feed, and other products. Microbial Cell Factories, 17(1):36-57. DOI: 10.1186/s12934-018-0879-x.

Widianingsih, Hartati, R., Endrawati, H. \& Iriani, V.R. 2012. Kandungan Lipid Total Nannochloropsis oculata Pada Kultur dengan Berbagai Fotoperiod. IImu Kelautan, 17(3):119124. DOI:10.14710/ik.ijms.17.3.119-124

Xu, Y., Ibrahim, I.M. \& Harvey, P.J. 2016. The influence of photoperiod and light intensity on the growth and photosynthesis of Dunaliella salina (chlorophyta) CCAP 19/30. Plant Physiology and Biochemistry, 106:305-15. DOI: 10.1016/j.plaphy.2016.05.021.

Yusof, N.S., Yeong, Y.S., Zakeri ,H.A., Wahid ,M.E.A., Ghafar, S.N.A. \& Yusuf, N. 2021. Photoperiod influenced the growth and antioxidative responses of Chlorella vulgaris, Isochrysis galbana, and Tetraselmis chuii. Journal of Applied Pharmacetical Science., 11 (4):125-134. DOI: 10.7324/JAPS.2021.110415. 